\title{
KEUNIKAN KRISTUS DALAM TEOLOGI MODERN
}

\author{
Adi Putra
}

\section{A. Pengantar}

Kristologi modern memiliki pergumulan yang sedikit berbeda dengan Kristologi gereja mulamula. Isu-isu seperti pluralisme, kemiskinan, perang, penderitaan, bencana alam, dan sebagainya, menjadi urgen dalam Kristologi modern. Sehingga pendekatan Kristologi modern lebih conditional atau kontekstual. Artinya, belajar dan menyelidiki Kristologi dalam bingkai pluralisme, kemiskinan, perang, penderitaan, bencana alam dan sebagainya. Inilah yang menjadi keunikan dari Kristologi modern.

Menurut Lumintang, "Persoalan teologi Kristen adalah berakar pada persoalan Kristologi. Oleh karena itu untuk menilai posisi teologi seseorang, apakah ia seorang Injili atau pluralis, universalis, atau gabungan dari dua di antaranya, bahkan gabungan dari ketiganya, harus mempelajari selain sistem hermeneutikanya juga kristologinya... Mengenal posisi teologi seseorang, harus berangkat dari akar teologi yakni Kristologi”. 1

Tentu dalam konteks Kristologi modern, yang mereka tolak adalah kristologi yang dahulu telah dirumuskan dalam konsili di Kalsedon. Di mana dalam konsili tersebut telah diterbitkan pengakuan Gereja tentang kemanusiaan sejati dan keilahian sejati dari Yesus Kristus, sebagai Pribadi kedua dari Allah Tritunggal. Kristologi seperti inilah yang ditolak atau direvisi ulang oleh para teolog modern. Hal ini bukanlah persoalan sepeleh, oleh karena mereka langsung menyerang 'jantung' kekristenan. Seperti yang dikatakan oleh Lumintang di atas.

Berikut ini akan dibahas pandangan teologi modern tentang Kristus yang diwakili oleh beberapa tokohnya seperti: Rudolf Bultmann, John Hick, dan Paul F. Knitter. Tidak hanya itu, dalam tulisan ini juga akan menyinggung sedikit tentang Kristologi dalam kelompok Anglikan Unitarian, Kristologi dalam teologi Pembebasan, Kristologi dan proses filosofi, serta Kristologi fungsional. Setelah itu akan dibahas dampak Kristologi Modern kepada kekristenan dalam zaman modern.

\section{B. Keunikan Kristus dalam Teologi Modern}

Kamus Besar Bahasa Indonesia mendefinisikan kata keunikan sebagai sifat (keadaan, hal) unik; kekhususan; keistimewaan. Kata dasarnya adalah unik yang diartikan tersendiri dalam bentuk atau jenisnya; lain daripada yang lain; tidak ada persamaan dengan yang lain; khusus.2 Berdasarkan definisi di atas, maka tulisan ini sebenarnya hendak membahas tentang Kristologi yang berbeda dari Kristologi sebelumnya atau yang lebih dikenal dengan sebutan kristologi eksklusif atau tradisional terutama mengacu kepada Kristologi yang telah dirumuskan dalam Konsili Kalsedon.

Dalam bukunya Jesus and the Other Names, seperti yang dikutip oleh Adiprasetya, di mana Knitter berusaha membuat klarifikasi mengenai terminologi unik. Menurutnya, unik tidak perlu menunjukkan tidak adanya sesuatu yang lain. Keunikan seseorang lebih berarti sesuatu yang membuatnya spesial, khusus dan berbeda, yang tanpanya orang itu tidak menjadi pribadi sebagaimana adanya dia. Atau dengan menghilangkan kualitas yang unik tersebut, maka tentu akan berjumpa dengan pribadi yang berbeda. Bagi Knitter, Yesus dikatakan unik oleh karena tanpa keunikan tersebut maka pribadi Yesus bukan lagi seperti yang dinyatakan dalam Alkitab. 3

1 Stevry Indra Lumintang, Teologi Abu-abu. Pluralisme Iman: Kristologi Abu-abu, (Malang: Departemen Literatur YPPII, 2002), hlm. 1. (dalam bentuk PDF).

2 Tim Penyusun, Kamus Besar Bahasa Indonesia Edisi Ketiga, (Jakarta: Balai Pustaka, 2002), hlm. 1247.

3 Joas Adiprasetya, Mencari Dasar Bersama, (Jakarta: BPK Gunung Mulia, 2009), hlm. 99-100. 
Kemudian Knitter memberikan beberapa alasan alkitabiah 'mengapa dia mengatakan Kristus unik?', seperti yang dikutip oleh Adiprasetya berikut ini:

Pertama, sejak semula karya Yesus memang terarah kepada Allah Bapa, atau tepatnya Kerajaan Allah. Yesus tidak pernah memberitakan diri-Nya sendiri, melainkan mewartakan Kerajaan Allah dalam kancah hidup manusia yang membawa keselamatan bagi manusia (kingdom- centrism atau soteriocentrism)... Kedua, harus disadari bahwa sejak semula kristologi yang dipaparkan dalam Alkitab ternyata beragam. Tidak pernah ada definisi tentang siapa Kristus, tetapi yang ada hanyalah interpretasi-interpretasi tentang siapa Yesus. Artinya, tidak boleh ada Kristologi yang dimutlakkan dan meniadakan kristologi yang lainnya. Ketiga, klaim bahwa Kristus sebagai Juruselamat satu-satunya (the one and only) tidak boleh dipandang secara harfiah, melainkan lebih kepada sebuah ungkapan pengakuan iman...sehingga kita harus lebih terbuka kepada pengakuan iman agama lain.4

Namun bagi penulis, kristologi modern dapat dikatakan unik, istimewa atau khusus, oleh karena memiliki penekanan tersendiri berdasarkan pergumulan pada zaman itu. Namun arti kekhususannya tidak menunjuk kepada validitasnya, melainkan lebih kepada aspek untuk menanggapinya. Maksudnya, ketika Kristologi Modern dikatakan unik, hal itu berarti perlu diperhatikan secara khusus. Atau tidak boleh dipandang sepeleh, oleh karena pengaruhnya yang sangat cepat menyebar dalam Gereja. Setidaknya, melalui tulisan ini memberikan secercah pengetahuan untuk mengerti dan memahaminya guna menjaga untuk tidak disesatkan.

\section{Rudolf Bultmanns}

Bultmann adalah seorang ahli Perjanjian Baru, ahli bahasa, seorang filsuf yang hidup sezaman dengan Paul Tillich dan Karl Barth. Dia adalah teolog yang terkemuka pada abad ke-20. Pada mulanya dia termasuk dalam kelompok Karl Barth, namun kemudian memutuskan untuk berjalan sendiri. Dalam sejarah teologinya, dikenal dengan demythologizing. Hal ini tidak terlepas dari pemahamannya bahwa manusia modern diperhadapkan dengan banyak kesulitan ketika membaca untuk mengerti Perjanjian Baru. Dengan bantuan demythologizing dari Bultmann, maka manusia modern dapat menemukan inti berita Perjanjian Baru. dan hal ini disebut dengan kerygma. Yang isinya tentang isi Perjanjian Baru yang Bultmann anggap sebagai mitos belaka. Untuk dapat menemukan kerygma di dalamnya maka mitos tadi harus ditafsirkan, tidak membuang mitosmitos tersebut melainkan mengupas dunia kunonya sehingga terkuak arti yang dapat dipahami oleh manusia modern.6

Kristologi Bultmann seperti yang dikemukakan oleh Macleod adalah Kristologi yang hanya berpatokan pada pengajaran Kristus yang sama sekali tidak memiliki kaitan dengan redemption (penebusan). Atau yang umumnya dikenal dengan the Christ-Event (Peristiwa Kristus). Bagi Bultmann, Peristiwa Kristus ini disebut dengan kerygma, yang dibaginya ke dalam dua tingkatan.

Tingkatan pertama adalah pengajaran Yesus sendiri. Akan tetapi Macleod menganggap bahwa di sini jelas menunjukkan inkonsistensi dari Bultmann dengan berkata, "This immediately strikes one as inconsistent with Bultmann's starting-point. If we can know nothing of the life or personality of Jesus, how can we know what he tought? Part of Bultmann's answer to this is that we can be much more certain with regard to Jesus' teaching than we can regard to his life and

4 Ibid., hlm. 100-1.

5Rudolf Karl Bultmann (20 Agustus 1884 - 30 Juli 1976) adalah seorang teolog Jerman dengan latar belakang Lutheran, yang selama tiga dasawarsa menjadi profesor dalam studi Perjanjian Baru di Universitas Marburg. Bukunya History of the Synoptic Tradition (Sejarah Tradisi Sinoptik) (1921) hingga kini masih dianggap sebagai perangkat penting dalam penelitian kitab-kitab Injil, bahkan oleh para sarjana yang menolak analisisnya tentang trope retorika konvensional atau satuan naratif yang membentuk kitab-kitab Injil, dan prinsip-prinsip yang berorientasi sejarah yang disebut "kritikbentuk".

(Sumber: http://id.wikipedia.org/wiki/Rudolf_Bultmann//16/10/2012//)

6 F. D. Wellem, Riwayat Hidup Singkat Tokoh-tokoh dalam Sejarah Gereja, (Jakarta: BPK Gunung Mulia, 2011), hlm. 46-7. 
personality".7 Jadi bagi Macleod, bagaimana mungkin bisa mengetahui pengajaran Kristus sedangkan tidak tahu tentang kehidupan dan pribadi Yesus Kristus itu sendiri.

Yang lain yang lebih radikal lagi adalah ketika sebuah pengajaran datangnya dari orang lain. Apa artinya? Menurutnya, lebih baik untuk menaruh nama "Yesus" dalam tanda kutip dan dianggap sebagai sebuah singkatan untuk menunjukkan bahwa itu hanya dapat dipahami sebagai sebuah pesan, sebaliknya bukan pribadi atau kisah-Nya. Dan itu merupakan kelanjutan dari Peristiwa Kristus. Ketika peristiwa Kristus ini sampai kepada manusia, maka di situlah dapat dilihat sebagai hari untuk memutuskan telah datang, dan Yesus atau "Yesus" memanggil untuk bertobat dan mengasihi.8 Jadi, menurut Bultmann, apabila ajaran Yesus itu datang melalui orang lain, sebaiknya nama "Yesus" ditempatkan dalam tanda kutip yang menandakan bahwa itu hanya pesan bukan pribadi Yesus atau bukan juga sejarah-Nya.

Tingkatan yang kedua dari kerygma, terdapat dalam ajaran gereja mula-mula. Menurut Bultmann, hal ini telah menjelaskan elemen dari mitologi seperti klaim bahwa Yesus telah dibangkitkan dari kematian serta penyataan bahwa Dia adalah Tuhan dan Anak Allah. Allah telah bekerja dengan nyata di dalam sejarah: bukan dalam beberapa peristiwa lampau, akan tetapi di dalam pengajaran itu sendiri. Pengajaran ini memanggil kepada keputusan yang berisi salib dan kebangkitan. Untuk dapat mengerti atau percaya kepada salib hanya melalui kerelaan untuk disalibkan bersama dengan Kristus. Dalam hal ini berarti menderita atau penderitaan.9 Seperti yang dikemukakan oleh Galloway bahwa, "The proclamation (kerygma) is not simply a message about Jesus. It is an event in which we meet Jesus and encounter his challenge".10 Artinya pesan itu harus direspon dengan turut merasakan penderitaan seperti dahulu Kristus telah menderita.

Dalam metode demitologisasi yang dikemukakan oleh Bultmann (guna mengerti dan memahami setiap isi dari Kitab Suci, khususnya Perjanjian Baru), sangat yakin bahwa kehidupan Yesus menawarkan teologi dalam bentuk cerita, yang pada waktu itu disajikan dalam bahasabahasa mitos. Akan tetapi semuanya tidak boleh dibuang, melainkan perlu untuk ditambahkan penjelasan agar dapat dipahami oleh orang Kristen masa kini. Oleh karena itu diperlukan filsafat eksistensial11 (dari koleganya Martin Heidegger) guna membuat ajaran-ajaran Yesus dapat dipahami oleh Gereja di zaman sekarang.12

Akan tetapi bagi Macleod sendiri, "But if the above summary of his thought is substantially correct, Bultmann's theology clearly labours enormous difficulties".13 Artinya, bagi Macleod dalam teologi Bultmann sendiri berdasarkan apa yang sudah dijelaskan di atas, akan dijumpai banyak sekali kesulitan, seperti:

a. Injil adalah Kabar Baik, dan itu berisi fakta atau peristiwa yang betul-betul terjadi. Sedangkan Bultmann menyebutkan bahwa isi Injil itu hanya sedikit berisi fakta dan lebih banyak mengenai perintah atau apa yang harus diperbuat. Sehingga keselamatan bergantung pada kerelaan dengan permohonan yang dibuat dalam kerygma (Berita Injil); di mana harus datang kepada sebuah keputusan, harus bertobat dan harus mengasihi; harus disalibkan bersama Kristus. Dalam ukuran manapun, banyak permohonan yang sulit dikabulkan, terutama sekali ketika tidak ada pertolongan ajaib (grace) yang tersedia, bahkan boleh dikatakan Injil dapat dengan mudah menjadi bahan dari sebuah perbudakan

7 Donald Macleod, The Person Of Christ. Contours of Christian Theology, (Illinois: InterVarsity Press, 1998), pp. 232-33.

8 Lihat: Donald Macleod, p. 233 §1.

${ }^{9}$ Lihat: Donald Macleod, p. 233 §2.

10 Gallian R. Evans, Alister E. McGrath dan Allan D. Galloway, The Science Of Theology Volume One, (Michigan: Grand Rapids, 1986), p. 323. [Editor: Paul Avis].

11 Eksistensialisme adalah aliran filsafat yang pahamnya berpusat pada individu manusia yang bertanggung jawab atas kemauannya yang bebas, tanpa memikirkan secara mendalam mana yang benar dan mana yang tidak benar. Sebenarnya bukannya tidak mengetahui mana yang benar dan mana yang tidak benar, tetapi seorang eksistensialis sadar bahwa kebenaran bersifat relatif, dan karenanya masing-masing individu bebas menentukan sesuatu yang menurutnya benar. (Sumber: http://id.wikipedia.org/wiki/Eksistensialisme//15/10/2012//).

12 http://id.wikipedia.org/wiki/Rudolf_Bultmann/15/10/2012//

13 Donald Macleod, ibid., p. 233. 
yang baru. Bahkan yang lebih buruk lagi, di mana adanya tantangan untuk mengambil sebuah keputusan, pertobatan dan mengasihi. Tidak ada Juruselamat yang dibangkitkan, bahkan tidak ada Imam Besar yang bersimpati dengan kelemahan-kelemahan dalam dosa. Tidak ada kenyamanan dalam kesedihan, sebab kematian tidak memberikan harapan untuk melihat mereka yang telah mati. Tidak ada Surga, dan semua diskusi tentang kemuliaan Kristus seolah-olah 'bersiul dalam kegelapan'.

b. Kerygma Bultmann tampak dengan utuh dilepaskan dari norma-norma historis. Melalui pintu masuknya sendiri, itu bersifat discontinuitas pada hampir setiap detil dari pesan para Rasul. Apa yang para Rasul anggap inti, dia anggap bukan sebuah pokok. Apa yang dia anggap inti, justru para Rasul jarang menyebutnya.

Masalah tidak berhenti sampai di situ. Oleh karena ada gap antara kerygma kekristenan mula-mula dengan pengajaran dari Yesus sendiri. Atau mungkin dari hal yang lain, antara "Yesus" dengan Yesus. Perkataan dalam pengajaran itu dihadapkan kepada kekristenan sebagai Firman Allah. Ini bukan untuk mempertanyakan mandatnya. Justru di sini orang Kristen yang ditanyakan, orang Kristen yang diminta apakah akan percaya kepada perkataan dalam pengajaran ataukah menolaknya. Tidak bisa dikatakan: "Kerygma benar karena secara esensinya berasal dari pengajaran Yesus'.

Ini tentu hanya akan menjadi rasionalisme belaka. Akan tetapi rasionalisme belaka memisahkan ini dari fakta aslinya. Sialnya untuk Bultmann sendiri, hal ini menjadi dilema. Bultmann tidak dapat berseru kepada Roh Kudus oleh karena Roh Kudus juga hanyalah mitos.

c. Sulit untuk melihat asumsi-asumsi dari Bultmann, di mana Kristus dapat dianggap unik, atau tetap khusus. Dengan jelas, Yesus tidak unik dalam pengertian metafisik. Sebab Dia tidak bereksistensi, Dia bukan seorang Penebus karena konsep penebusan adalah sebuah mitos. Sulit juga untuk mengatakan Dia tidak memiliki dosa, oleh karena tidak ada pengetahuan tentang kehidupan dan pribadi-Nya. Dia tidak unik pada keberadaan setelah kebangkitan dan kenaikan-Nya ke Sorga.

Dapatkah Yesus dianggap unik dalam keberadaan-Nya sebagai objek dari iman Kristen dan kehidupan devosi Gereja? Dalam kerygma kekristenan selanjutnya menyamakan 'iman' dengan iman dalam Kristus, namun pada dirinya sendiri tidak. Di mana menurut Bultmann, Yesus tidak mengajarkan dirinya sendiri, melainkan Allah Bapa.

Keunikan dari kerygma adalah tindakan pengajaran itu sendiri. Ini tidak dapat disebut pengajaran tentang Yesus oleh karena ketidaktahuan tentang Yesus. Dapatkah ini menjadi pengajaran yang diminta untuk iman dalam Yesus dan percaya dalam pekerjaannya, seperti pengajaran sebagai sebuah penemuan (ciptaan) Gereja mula-mula. Ini tidak dapat menjadi pengajaran yang asli sebagai kelanjutannya dengan Yesus sebab yang ada hanya sisa dalam ketidaktahuan dari asal-usul sejarah pengajaran ini.14

Grenz dan Olson juga memberikan informasi tentang konsep Bultmann, yakni: "Even the New Testament itself, as a document of the proclamation of the early church, focuses its concern on the Christ of the kerygma, not on the facts concerning the historical Jesus... Faith is not knowledge of historical facts, but a personal response to the Christ confronted in the gospel message... In this situation, faith can only be the gift of God's grace that comes to us in the kerygma... Theorists, including Bultmann, claimed that the New Testament reflected the use of the myths of the mystery religions, especially the myth of the descent of a redeemer god, to describe the work of Jesus the Christ".15 Intinya Bultmann tetap menganggap kerygma inti untuk bisa mengalami peristiwa Yesus dan juga untuk bisa menerima anugerah Allah, serta penebusan yang dikerjakan oleh Kristus hanya dipahami dalam konteks mitos.

Wilson dalam bukunya Introduction to Theology Modern mengemukakan, "His (Bultmann) separation of the 'Jesus of History' from the 'Christ of faith', the division of history into objective and eschatological (existential), as well as demythologizing and existential interpretation... he did not demythologize the supernatural act of God in Christ's cross and resurrection. They called for demythologizing the kerygma of cross and resurrection, for dekerygmatizing... While Bultmann

14 Lihat: Donald Macleod, pp. 234-5.

15 Stanley J. Grenz, dan Roger E. Oslon, 20тн Century Theology. God and the World in a Transitional Age, (Illinois. USA: InterVarsity Press, 1992), pp. 88-9. 
thinks we can know nothing of Jesus' teaching, even if in the Synoptic Gospels it is seen through the lens of the early church... A group of Bultmann's student's challenged the distinction between the historical Jesus and the Christ of the kerygma. They argued that the teaching of the historical Jesus in the Synoptic Gospels is essentially the same authoritative Word of God that is in Paul's proclamation of the crucified and resurrected Christ".16 Bultmann membedakan antara Yesus sejarah dari Kristus iman dengan ekspektasi eskatologis seperti halnya demithologisasi dan eksistensialisme. Akan tetapi Bultmann tidak menerapkan demitologisasi aktivitas supranatural dari Allah dalam salib Kristus dan kebangkitan, meskipun mereka menggunakan demitologisasi kerygma. Dan bagi Bultmann tidak mungkin untuk bisa mengetahui pengajaran Yesus, karena apa yang ada dalam Injil Sinoptik dilihat melalui kacamata gereja mula-mula. Meskipun murid dari Bultmann sendiri tidak dengan sepenuhnya setuju dengan apa yang dikemukakan oleh Bultmann.

Dalam pandangan Bultmann, "pemikiran teologis" Perjanjian Baru atau teologi Perjanjian Baru dimulai dengan kerygma gereja mula-mula dan bukan yang sebelumnya, pada masa Yesus hidup di dunia. Bagi gereja mula-mula, kerygma sebagai tindakan pemberitaan. Artinya, kerygma itu memproklamasikan Yesus Kristus, yaitu Yesus Kristus yang tersalib dan bangkit sebagai tindakan penyelamatan Allah yang bersifat eskatologis. Kristus yang seperti inilah pertama-tama diberitakan dalam kerygma Gereja paling dini, bukan dalam pemberitaan dari Yesus historis. 17

Jadi, menurut Bultmann kerygma dalam Perjanjian Baru adalah tindakan proklamasi eskatologis yang telah dimulai oleh Yesus dengan pemberitaan-Nya dan diteruskan Gereja mulamula melalui memberitakan Yesus Kristus yang dibangkitkan sebagai penggenapan pengharapan tersebut. Semasa hidup-Nya, Yesus hanya pemberita pemerintahan Allah yang eskatologis. Tetapi bagi gereja mula-mula, kehadiran Yesus dan kisah hidup-Nya selanjutnya (kematian sampai kenaikan-Nya) dihayati sebagai kegenapan berita yang disampaikan Yesus. Di dalam Kristus, pemerintahan Allah dinyatakan. Konsep inilah yang sering disebut sebagai "peristiwa Kristus".

Singkatnya, Bultmann beranggapan bahwa Yesus memang pernah hidup dalam sejarah. Akan tetapi apa yang dikerjakan, diberitakan oleh Yesus adalah pekerjaan Allah Bapa. Sebenarnya Dia bukanlah Allah atau Juruselamat, namun Gereja mula-mula yang mempunyai andil di dalam transformasi Yesus menjadi Allah dan Juruselamat. Ketika Gereja mula-mula memberitakan tentang Yesus sebagai Mesias (Kristus), maka hal ini bukanlah sebuah fakta melainkan hanyalah rekayasa Gereja saja. Sehingga bagi Bultmann, Yesus disebut Kristus hanya dapat dipahami dalam perspektif iman. Pendekatan yang digunakan oleh Bultmann adalah pendekatan kerygma untuk pokok yang pertama, sedangkan pendekatan demitologisasi kerygma untuk pokok yang kedua.

Sebagai tambahan, Bultmann juga menganggap kebangkitan Yesus tidak memiliki efek sama sekali terhadap iman Kristen. Apakah Yesus betul bangkit atau tidak, itu bukanlah masalah yang berarti dan sama sekali tidak akan merubah iman Kristen. Seperti yang dikutip oleh Kreeft dan Tacelli bahwa, "Apabila tulang-belulang Yesus yang telah mati ditemukan besok di kuburan Palestina, maka seluruh pokok penting dalam ajaran Kristen akan tetap tidak berubah". 18 Padahal sudah dengan tegas dan jelas Paulus kemukakan dalam 1Korintus 15:14 tentang kesia-siaan iman Kristen dan pemberitaan Injil andaikata Yesus tidak bangkit. Menunjukkan bahwa kebangkitan Yesus memiliki tempat yang urgen dalam iman Kristen.

16 John E. Wilson, Introduction to Modern Theology. Trajectories in the German Tradition, (London: Westminster John Knox Press, 2007), pp. 203-4.

17 http://alkitab.sabda.org/resource.php?topic=1046\&res=jpz/16/10/2012//

18 Peter Kreeft dan Ronald K. Tacelli, Pedoman Apologetik Kristen Jilid 1, (Bandung: Yayasan Kalam Hidup, 2006), hlm. 234. Cetakan Kedua. 


\section{John Hick19}

Pada bagian ini akan dibahas pandangan Hick tentang Inkarnasi. Di mana John Hick berpandangan, inkarnasi harus dipahami dalam pengertian mitos, dan hal ini jelas dalam bukunya yang berjudul The Myth Of God Incarnate. Menurut Macleod, Hick setuju dengan konsep 'historical scepticism' dari Bultmann. Bahkan ditambahkan oleh Macleod bahwa, "They also agree that incarnation is a myth, that is, a story which is not literraly true, but which is told to elicit a particular response from the hearers".20 Akan tetapi dalam penjelasan Lumintang menerangkan bahwa, "Dalam perkembangan selanjutnya, konsep inkarnasi Hick mengalami perubahan, di mana ia berargumentasi bahwa yang terbaik untuk memikirkan mengenai penjelasan inkarnasi dalam Alkitab, adalah inkarnasi tersebut dipahami sebagai metafora".21

Alasan Hick mengemukakan inkarnasi metafora adalah untuk menolak pandangan tradisional tentang inkarnasi. Hal ini tidak terlepas dengan konsep soteriologisnya yang merupakan hasil transposisi manusia, bukan melalui karya yang Yesus telah kerjakan. Konsep pengantara (mediator) yang diperankan oleh Yesus hanyalah kebohongan belaka, oleh karena baginya tidak mungkin ada karya penebusan yang memampukan Allah untuk mengampuni. Dalam pemahaman Hick, yang mengampuni dosa adalah Allah Bapa, tidak harus melalui Yesus. Seperti yang diceritakan dalam Perumpamaan tentang Anak yang Hilang (Luk. 15: 20-24).

Bagi Hick, "In the case of Christianity, believers gradually began to apply to their founder concepts he had not applied to himself. This process was completed when 'the Son of God' became 'God the Son'. This transformation is most apparent in the Gospel of John and became indigenized in the church as a result of the uncritical (or pre-critical) acceptance of this gospel".22 Jadi, keyakinan Hick adalah Yesus bukan Allah, tetapi orang Kristen mula-mula yang telah menjadikan-Nya Allah. Dan perubahan (transformasi) seperti ini sangat jelas dalam Injil Yohanes. Kemudian pada Konsili di Nicea diputuskan bahwa Yesus dari Nazareth secara substansi sama dengan Allah Bapa (homoousis).23

Dalam bukunya yang berjudul Pengantar Ke Dalam Teologi Agama-Agama, Paul F. Knitter menyinggung sekilas tentang Kristologi dari Hick:

Yesus merupakan satu-satunya penghubung antara Tuhan dan manusia. Oleh karena itu, orang-orang Kristen tidak meninggalkan keyakinan mengenai inkarnasi dan Yesus sebagai anak Allah. Dalam pernyataan ini dapat dilihat adanya unsur puitis, simbolis dan metafora.

Pernyataan bahwa Yesus adalah anak Allah menunjukkan sikap, perasaan, dan keyakinan. Pernyataan ini lahir karena orang-orang Kristen sudah merasakan Allah berbicara kepada mereka, menyentuh mereka, memberi inspirasi kepada mereka melalui Yesus.

Untuk memahami Yesus sebagai anak Allah dalam bahasa simbolis, Hick menyarankan agar menggunakan Kristologi Roh untuk memahami hal ini. Di dalam Kristologi Roh, Yesus dikenal sebagai ilahi bukan karena Allah secara harafiah turun dari Surga dan secara harafiah juga menghamili ibu Yesus, tetapi karena Yesus memang dipenuhi Roh yang diberikan kepada semua orang dan memberi respon total terhadap roh itu.

Hick meringkaskan pemahamannya mengenai keunikan Yesus dalam bahasa Latin, umat Kristen di hadapan sesama umat Kristen dan agama lain harus menyaksikan bahwa Yesus adalah totus Deus Tuhan seutuhnya. Namun mereka tidak bisa beranggapan bahwa Ia adalah totum Dei - Tuhan keseluruhan. Siapa Yesus itu, semua yang ia lakukan dan yang ia katakan diperoleh dari, dan dinyatakan oleh, Roh Ilahi. Namun, siapa Roh Ilahi itu dan apa yang dilakukan tidak hanya terbatas pada Yesus, atau kepada inkarnasi Ilahi manusia siapa pun.24

19 Nama lengkapnya adalah John Harwood Hick. Dia lahir di Yorkshire, Inggris tahun 1922. Dia adalah seorang Teolog yang mendapatkan pendidikan teologi di Edinburg dan Oxford. John Hick adalah tokoh yang terkenal dengan pluralime, dialog antar agama-agama. [Sumber: http://id.wikipedia.org/wiki/John_Hick//17/10/2012//].

20 Donald Macleod, p. 235.

21 Stevry Indra Lumintang, hlm. 8.

22 Donald Macleod, p. 235.

23 Lihat: Donald Macleod, p. $235 \S 4$.

24 Paul F. Knitter, Pengantar Ke Dalam Teologi Agama-Agama, (Yogyakarta: Kanisius, 2008), hlm. 134-145. 
Dari apa yang dikemukakan oleh Hick di atas, maka dapat dilihat ada beberapa pokok dari Kristologi Hick, yakni: (1) Inkarnasi Yesus sebagai Anak Allah dan sebagai satu-satunya penghubung antara Tuhan dengan manusia harus dipahami bahwa itu memiliki unsur yang puitis, simbolis serta metafora; (2) Untuk memahami unsur simbolis di atas, Hick menyarankan untuk menggunakan Kristologi Roh, artinya: secara harfiah Dia bukan Allah, Dia hanya manusia yang dipenuhi oleh Roh di mana kemungkinan terjadi kepada orang lain sangat besar; (3) Roh Ilahi yang bekerja dalam Yesus masih dapat dijumpai dalam manusia-manusia yang lain, sehingga keselamatan bukanlah sesuatu yang eksklusif melainkan inklusif. Oleh karena Allah bisa saja memunculkan tokoh-tokoh yang seperti Yesus di agama-agama lain.

Hal di atas tidak jauh berbeda dengan apa yang dikemukakan Lumintang dalam bukunya Teologi Abu-abu, tentang tiga alasan Hick menolak kristologi tradisional atau eksklusif. Dan sebaliknya mengemukakan kristologi metaforis, adalah sebagai berikut:

a. Bagi Hick, sangat sulit untuk menerima jika Yesus yang adalah Allah Pencipta berinkarnasi menjadi manusia. Sehingga dia menyimpulkan bahwa inkarnasi Yesus adalah salah satu dari sekian banyaknya inkarnasi dalam dunia Romawi, di mana tidak harus dipahami sebagai Allah yang mengambil rupa manusia.

b. Inkarnasi Yesus tidak dapat dipahami dalam arti yang literal, melainkan sebagai aplikasi dari konsep mistis tentang sebuah analogi yang mengilahikan Anak. Bagi Hick sendiri inkarnasi hanyalah sesuatu yang bersifat mistis atau tidak mungkin terjadi secara nyata [Bukankah pendapat ini berkontradiksi dengan pendapatnya pada nomor 1].

c. Bagi Hick konsep inkarnasi hanya merupakan ciptaan gereja mula-mula. Pada dirinya sendiri, Yesus tidak merasa melalui cara yang demikian. Sehingga sebutan Anak Allah, Allah Anak, Mesias dan kemudian Tritunggal, itu semua adalah produk Gereja [Tentu hal ini dilatarbelakangi dengan presuposisi kaum pluralis yang tidak lagi menerima doktrin inspirasi Alkitab].

Jadi, konsep Hick yang menyatakan bahwa inkarnasi hanyalah mitos merupakan penyesatan yang melawan inti dari agama Kristen. Oleh karena justru dengan doktrin inkarnasi, maka membuat kekristenan unik di tengah-tengah agama lain di dunia ini. Seperti pernyataan Hebblethwaite, yang dikutip oleh Nash berikut ini:

Doktrin inkarnasi adalah salah satu kepercayaan yang menjadikan kekristenan unik di tengah-tengah agama-agama dunia. Orang Kristen percaya bahwa Allah Tritunggal yang berdaulat, yang dapat dikenali hanya karena Dia berkehendak untuk mewahyukan diri-Nya, telah 'membuat membuat diriNya dikenal oleh kita, dengan cara yang paling langsung dan komprehensif yang mungkin ada, yaitu dengan cara menjadi salah satu di antara kita dan berbagi dengan kehidupan kita, dalam suka dan duka, dan sukacita maupun penderitaan. 25

\section{Paul F. Knitter}

Paul F. Knitter lahir di Chicago, Amerika Serikat pada tahun 1939. Dia adalah seorang teolog Katolik Roma yang berperan dalam mengembangkan diskursus teologi agama-agama. Dia dikenal sebagai salah seorang pendukung posisi pluralisme bersama dengan para teolog lain, seperti Alan Race dan John Hick. Selain itu, Knitter juga dikenal sebagai pelopor dialog antar-iman.26

Berkaitan dengan keunikan Kristus, Knitter mengakui bahwa Yesus Kristus memang unik. Akan tetapi keunikan-Nya ditentukan oleh kemampuan-Nya dalam berelasi dengan figur agama lain yang juga unik. Keunikan ini disebut keunikan relational. Bagi Knitter, keunikan tersebut konsisten dengan pendirian teologis pluralis yang teosentris. Di mana Yesus dianggap sebagai

25 Ronald H. Nash, Konflik Wawasan Dunia, (Surabaya: Momentum, 2008), hlm. 200.

26 http://id.wikipedia.org/wiki/Paul_F._Knitter/20/10/2012// 
pelayan Allah yang berfungsi sebagai Juruselamat, sama seperti figur agama lain yang juga terarah kepada Allah.27

Seperti yang sudah dibahas sebelumnya, tentang tiga pandangan alkitabiah yang menunjukkan keunikan Yesus Kristus, seperti yang dikutip oleh Adiprasetya (lihat dalam hlm. 2, § 1) adalah sebagai berikut:

a. Sejak semula karya Yesus memang terarah kepada Allah Bapa, atau tepatnya Kerajaan Allah. Yesus tidak pernah memberitakan diri-Nya sendiri, melainkan mewartakan Kerajaan Allah dalam kancah hidup manusia yang membawa keselamatan bagi manusia (kingdom- centrism atau soteriocentrism)

b. Harus disadari bahwa sejak semula kristologi yang dipaparkan dalam Alkitab ternyata beragam. Tidak pernah ada definisi tentang siapa Kristus, tetapi yang ada hanyalah interpretasi-interpretasi tentang siapa Yesus. Artinya, tidak boleh ada Kristologi yang dimutlakkan dan meniadakan kristologi yang lainnya.

c. Klaim bahwa Kristus sebagai Juruselamat satu-satunya (the one and only) tidak boleh dipandang secara harfiah, melainkan lebih kepada sebuah ungkapan pengakuan iman...sehingga kita harus lebih terbuka kepada pengakuan iman agama lain.

\section{Anglikan Unitarian}

Tokoh-tokoh terkenal kelompok ini seperti: John A. T. Robinson, G. K. W. Lampe, Don Cupitt, John Knox, Norman Pittenger, Denis Nineham, dan Maurice Wiles. Kekuatan utama dari perumusan kembali yang dilakukan oleh mereka terhadap Kristologi adalah sebuah kebencian yang sifatnya paranoid kepada docetisme, terutama kepada sebuah kecemasan dengan kemanusiaan Kristus dan kecenderungan untuk menyarankan hal itu pada Kristologi sebelum abad ke-20 (termasuk pengakuan seluruh gereja) yang diremehkan, apabila dulu belum sama sekali menghancurkan, kemanusiaan dari Yesus. Seperti sebuah pandangan yang jelas buruk pada kesenangan dengan keputusan konsili di Kalsedon. Dan ketidaksenangan itu tidak berhenti sampai di situ. Mereka juga menolak sifat historis dari pandangan yang ortodoks.

Penjelasan di atas seperti yang dikemukakan oleh Macleod dalam bukunya The Person of Christ, bahwa:

The main driving force behind their attemped reformulating of Christology is a paranoid aversion to Docetism, leading to an obsessive preoccupation with the humanity of Christ and a tendency to suggest that pre-twentieth century Christology (including that of the ecumenical creeds) minimized, if it did not quite destroy, the manhood of Jesus. Such an outlook is obviously ill at ease with Chalsedon. But the unease does not end there. 28

Mereka menolak kunci dari sifat historis pandangan ortodok. Seperti yang diuraikan dalam lima poin di bawah ini:

Pertama, mereka menolak doktrin inkarnasi. Sebagai contoh, Maurice Wiles yang menghormati inkarnasi hanya sebagai salah satu kemungkinan penafsiran dari signifikansi Yesus. Yang mana tidak secara langsung hadir dalam Kitab Suci serta tidak memiliki arti yang dapat dipahami.29

Kedua, Anglikan Unitarian menolak pre-eksistensi Kristus. Lampe menolak pre-eksistensi sebagai jalan yang menyesatkan dari pengakuan terhadap kualitas keilahian kemanusiaan Yesus. Hal yang serupa dikemukakan oleh John Knox dalam bukunya The Humanity And Divinity of Christ.30

\footnotetext{
27 Joas Adiprasetya, hlm. 99.

28 Donald Macleod, p. 241.

29 Lihat: Donald Macleod, p. $241 \S 5$.

30 Lihat: Donald Macleod, p. 241-2 §6.
} 
Ketiga, selain menolak pre-eksistensi Kristus, ternyata mereka juga menolak post-eksistensiNya. Hal ini secara eksplisit muncul dalam pernyataan Lampe, di mana dia menolak ide-ide dari kebangkitan tubuh, kenaikan ke Surga dan kiamat. Menurut Lampe, "Resurrection is the liberation of the life of the individual Jesus to become the life of all men whom God's Spirit that was in him refashions according to his likeness".31 Maksudnya, kebangkitan adalah pembebasan hidup Yesus dari oknum Yesus guna menjadi hidup dari semua manusia yang Roh Allah itu telah di dalamnya mengubahnya seturut gambarnya.

Keempat, mereka juga menolak rumusan trinitas tradisional atau ortodoks. Menurut Lampe, "kepribadian yang berbeda dari Roh Kudus dihilangkan dalam konsep Allah sebagai Roh. Yang mana pada gilirannya diturunkan kepada ide 'serangan yang berkesinambungan dari keilahian yang transenden kepada yang imanen yang berbelit-belit dalam proses penciptaan". Ditambahkan oleh Lampe, "pasti datang dalam sesuatu yang sangat sempit dari pengakuannya, pengumuman model Trinitarian itu adalah di dalam kepuasan yang tidak berujung untuk pengucapan dari dasar pengalaman kekristenan dari konsep Allah sebagai Roh yang seragam”. Lampe menyimpulkan, "Saya dengan pasti tidak mengklaim pandangan-pandangan yang telah saya kemukakan adalah compatible dengan cara yang pengakuan tradisional katakan".32

Kelima, mereka juga menolak keunikan Kristus. Misalnya, Maurice Wiles, mengakui itu untuk meninggalkan konsep inkarnasi tak terhindarkan di mana akan memimpin kepada pilihan yang laindi luar gereja. "The most likely change [perubahan yang hampir dipastikan]". Dia menambahkan, "akan menjadi lebih sedikit mendesak eksklusif pada Yesus sebagai jalan untuk semua orang dan untuk semua budaya". Untuk hal ini, dia berpendapat, tidak meliputi kesimpulan bahwa semua agama dengan nilai yang sama. Meskipun demikian, tindakan ini mengesampingkan pendapat dari keunggulan sebuah agama dari yang lain pada kemajuan dari sesuatu yang diberitahukan pengetahuan dari kedua kepercayaan. Seperti sebuah pilihan tidak hanya menjadi penghormatan sebagai keuntungan. 33

Berdasarkan kelima poin di atas, maka dapat dilihat dengan jelas bahwa kristologi kelompok ini menekankan, (1) menolak inkarnasi Yesus; (2) menolak pre-eksistensi Yesus; (3) menolak post-eksistensi Yesus; (4) menolak doktrin Trinitas; serta (5)menolak keunikan Kristus. Apabila melihat dengan baik kelima poin ini, maka memang tampak dengan jelas pokok-pokok ajaran dari sekte unitarian. Di mana mereka juga menolak konsep Allah Tritunggal. Selain itu kelompok Unitarian pun menolak konsep dosa asal serta doktrin predestinasi. Secara umum ajaran Unitarian lebih menekankan kebebasan manusia serta kebaikan Allah. Bagi mereka Roh Kudus tidak ada, sedangkan Yesus hanyalah manusia yang memiliki jabatan sebagai nabi yang hebat oleh karena mampu mengadakan mujizat.34

Jadi, pandangan kelompok Anglikan Unitarian memiliki kesamaan dengan dua pandangan yang telah dibahas sebelumnya, yakni: pandangan Bultmann dan Hick.

\section{Kristus dalam Teologi Pembebasan 35}

Teologi Pembebasan merupakan paham tentang peranan agama dalam hubungannya dengan lingkungan sosial. Namun bisa juga dipahami sebagai suatu usaha kontekstualisasi ajaran-ajaran dan nilai-nilai keagamaan pada masalah konkret di sekitarnya. Teologi Pembebasan adalah upaya

31 Donald Macleod, p. $242 \S 7$.

32 Lihat: Donald Macleod, p. $242 \S 2$.

${ }^{33}$ Lihat: Donald Macleod, p. $242 \S 3$.

34 http://id.wikipedia.org/wiki/Unitarianisme/19/10.2012//

35 Teologi Pembebasan muncul pada abad ke-20, seiring banyaknya permasalahan dunia yang sedang tidak merdeka dinilai dari sudut pandang keadilan sebagai manusia yang sama di hadapan Tuhan. Dunia harus merdeka dari tindakan yang menindas sesamanya, bahkan seharusnya yang kaya dan memiliki jabatan harus membela dan memperhatikan kebutuhan rakyat kecil dan miskin. Kemunculan pertamanya di Eropa yang berkonsentrasi pada persoalan globalisasi, berprihatin pada dosa sosial yang terdapat pada sistem pemerintahan sebuah negara. Teologi Pembebasan menawarkan sistem sosial yang mengedepankan keadilan sebagai warga negara dan warga dunia dalam pandangan agama (manusia yang adil, tidak tertindas)yang dirusak oleh manusia sendiri). Sementara itu, teologi pembebasan yang lahir di Amerika Latin berfokus pada gerakan perlawanan yang kebanyakan dilakukan oleh para agamawan terhadap kekuasaan yang hegemoni dan otoriter.

(Sumber: http://id.wikipedia.org/wiki/Teologi_pembebasan/20/10/2012//). 
berteologi secara kontekstual. Sehingga mengharuskan Gereja untuk berkomitmen juga memperhatikan kehidupan sosial dengan orang lain. Teologi pembebasan 'lahir' sebagai respons terhadap situasi ekonomi dan politik yang dinilai menyengsarakan rakyat. Masalah-masalah itu dijabarkan dalam penindasan, rasisme, kemiskinan, penjajahan, bias ideologi dan sebagainya. Pada kalangan Jesuit, baik di Asia termasuk Indonesia, Brazil, Amerika Latin, dan Afrika Selatan, teologi ini berkembang pesat sebagai dampak dari hermeneutika Alkitab secara kontekstual untuk menjawab persoalan yang dihadapi oleh umat manusia. Teologi Pembebasan merupakan refleksi bersama suatu komunitas terhadap suatu persoalan sosial. Karena itu masyarakat terlibat dalam perenungan-perenungan keagamaan. Mereka mempertanyakan seperti apa tanggung jawab agama dan apa yang harus dilakukan agama dalam konteks pemiskinan struktural.36

Knitter dalam bukunya No Other Name?, seperti yang dikutip Adiprasetya, juga berusaha mengaitkan topik keunikan Kristus dengan praksis pembebasan, antara teologi agama-agama dan teologi pembebasan. Lebih lanjut Adiprasetya mengemukakan pendapat Knitter, "Kaitan antara kedua teologi ini terletak pada pentingnya praksis. Yang harus diupayakan, menurut Knitter adalah sebuah Kristologi yang berbasis pada praksis (a praxis-based Christology)".37 Dalam analisis Adiprasetia terhadap pandangan Knitter ini, dia menyimpulkan bahwa ada empat hal penting sehubungan dengan itu, yakni:

Pertama, pengakuan dan pewartaan kristiani mengenai Yesus sebagai penyataan Allah yang final dan normatif tidak dapat berhenti pada perumusan doktrin atau pengalaman personal - oleh karena keunikan Kristus hanya dapat dikenal dan ditegaskan dalam pengejewantaan-Nya yang konkret, yaitu dalam praksis keterlibatan historis. Kedua, penekanan pada pentingnya praksis tidak lantas membuat kita berkata bahwa finalitas dan normativitas Yesus telah utuh dan dipenuhi - oleh karena praksis Yesus tidak memadai untuk menekankan keunikan Kristus. Ketiga, jika metode kristologi pembebasan memperlihatkan mengapa klaim normatif bagi Yesus tidaklah mungkin, maka jelaslah bahwa hal itu tidaklah perlu. Jika memang titik perhatian kita terletak pada praksis, maka pertanyaan doktriner mengenai keunikan Kristus menjadi tidak begitu perlu. Keempat, kristologi pembebasan mengizinkan dan bahkan menuntut kita untuk mengakui kemungkinan hadirnya pembebas lainnya dari agamaagama lain.38

Berdasarkan penjelasan Adiprasetya, maka dapat dinilai bahwa teologi pembebasan melihat Yesus dalam bingkai humanisme. Artinya Yesus tidak dapat dikenal dalam iman, melainkan harus dalam kehidupan praktis. Sehingga hal ini bermuara kepada sebuah konsep pluralis yang menyatakan bahwa besar kemungkinan akan muncul lagi pembebas-pembebas dalam agamaagama lain. Meskipun hal ini masih dalam taraf kemungkinan, akan tetapi hal ini menghilangkan sifat eksklusif dari Kristologi itu sendiri.

Sabrino dalam bukunya Christology at the Crossroad: A Latin American Approach, seperti yang dikutip oleh Macleod juga mendeskripsikan pandangan kristologi dalam konteks teologi pembebasan. Sabrino berkata demikian, "This means that Christ is not known through 'static contemplation' or cultic activity. We know him only as we follow him, particularly as we involve ourselves in implementing his programme".39 Kemudian Macleod menambahkan sedikit komentar dengan berkata, "From this standpoint, orthopraxis is more important than orthodoxy".40 Artinya, manusia hanya dapat mengalami Kristus dalam kehidupan praktis. Di mana dalam teologi pembebasan dianggap lebih penting dari kehidupan ortodoks.

Dengan demikian dapat dilihat dengan jelas bahwa keunikan Kristus dalam teologi pembebasan terletak dalam perspektif mereka terhadap Kristologi yang sifatnya praksis. Hal ini tentu tidak terlepas dari problem sosial yang ada. Akan tetapi dampaknya adalah hilangnya sifat eksklusif dari kristologi, di mana

\footnotetext{
36 http://id.wikipedia.org/wiki/Teologi_pembebasan/20/10/2012//

37 Joas Adiprasetya, hlm. 101.

38 Ibid., hlm. 101.

39 Donald Macleod, p. 252.

40 Ibid., p. 252.
} 
juruselamat (atau dalam istilah mereka pembebas) bisa saja muncul dari agama-agama lain. Jadi, Kristus bukan satu-satunya Juruselamat. Bahkan dalam penilaian penulis, Kristologi ini lebih bersifat humanis dan melihat Yesus tidak secara utuh (karena didasarkan pada penekanan kondisi sosial).

\section{Kristologi Fungsional}

Pada pokok ini, pertama-tama akan diperhatikan pandangan Cullmann41 yang berkembang pesat. Di mana dia berargumentasi bahwa Perjanjian Baru hanya memberikan sedikit perhatian kepada hakikat Kristus. Baginya, Perjanjian Baru memberikan perhatian hanya kepada tindakan Ilahi dan self-communication. Hal ini jelas dalam bukunya The Christology of the New Testament, seperti yang dikutip oleh Macleod bahwa, "By the very nature of the New Testament Logos one cannot speak of him apart from the action of God. Accordingly, we can speak of the deity of Christ only in the sense that he is the centre of divine revelation: Jesus Christ was God in so far as God reveals himself to the world".42 Artinya, bagi Cullmann sendiri keilahian Yesus ditentukan oleh penyataan Allah itu sendiri. Secara tidak langsung menolak pre-eksistensi Yesus sebagai Allah - sebuah pandangan yang mirip dengan pandangan kelompok Anglikan Unitarian.

Ditambahkan Cullmann, "functionalisme meant only that the New Testament had no interest in the being Christ outside of his mediatorial work and no interest in his natures apart from their manifestationin the history of salvation... any opposition between Chalcedon and the New Testament, Cullmann insisted that, the moment the question of the natures, though it is not itself present in the New Testament, is raised, the dogma formulated by this Council corresponds to what the Christology of the New Testament presupposes"43 Jadi, menurut Cullmann bahwa Perjanjian Baru hanya memperhatikan keberadaan Kristus berdasarkan karya-Nya untuk menyelamatkan manusia. Bagi Cullmann bahwa sebenarnya Perjanjian Baru tidak berbicara sama sekali tentang pre-eksistensi dari Yesus. Apabila itu ada dalam ajaran Kristen, itu merupakan hasil rumusan dari Konsili Kalsedon.

Macleod membantah konsep Cullmann ini dengan berkata, "We cannot, however, separate ontology from revelation in this way. Christ reveals God only because he is God: the revealer, the revelation and the revealed one are the same".44 Ditambahkan oleh Macleod, "This clearly accords with the New Testament presentation: Jesus reveals God because he is the Logos and as the Logos he is divine (Jn. 1: 1). We cannot reverse this and say instead that he is divine because he reveals God. He was Logos and God 'in the beginning' (Jn. 1: 1).45 Hal ini juga tampak dalam

41 Oscar Cullmann (25 February 1902, Strasbourg - 16 January 1999, Chamonix) was a Christian theologian in the Lutheran tradition. He is best known for his work in the ecumenical movement, being in part responsible for the establishment of dialogue between the Lutheran and Roman Catholic traditions. Because of his intense ecumenical work, Cullmann's Basel colleague Karl Barth joked with him that his tombstone would bear the inscription "advisor to three popes." He was invited to be an observer at the Second Vatican Council. Cullmann was born in Strasbourg (then in Germany) and studied classical philology and theology at the seminary there. In 1926 he accepted an assistant professorship, a position previously held by Albert Schweitzer. In 1930 he was awarded a full professorship of New Testament, beginning in 1936 to also teach the history of the early church. In 1938, he began teaching both subjects at Basel Reformed Seminary. In 1948 he accepted a position teaching theology in Paris at the Sorbonne while he continued at Basel. He retired from both in 1972. Cullmann's studies on Christian eschatology and Christology drove him to propose a third position over against the popular positions of C. H. Dodd and Albert Schweitzer, known as "redemptive history". He wrote that Jesus Christ was the midpoint of sacred history, which informs general history, and which runs linearly from creation to consummation. He stressed the objective reality of sacred history against the existentialist interpretation of Rudolf Bultmann, a fellow German theologian. Upon his death at age 96, the World Council of Churches issued a special tribute to Cullmann in honor of his ecumenical work. (Sumber: http://en.wikipedia.org/wiki/Oscar_Cullmann/20/10/2012//)

42 Ibid., pp. 245-6.

43 Ibid., p. 246.

44 Ibid.,

45 Ibid., p. 247. 
Kristologi Paulus yang menyatakan bahwa Kristus adalah gambar dari Allah, keserupaan Allah yang menyatakan kemuliaan Allah.

\section{Kristologi dan Proses Filosofi}

Yang mendasari Anglikan Unitarian adalah sebuah ketidak-percayaan yang didudukkan di dalam ide intervensi Ilahi dalam setiap urusan-urusan manusia. Ini yang menjadi alasan mengapa Maurice Wiles curiga kepada konsep inkarnasi dengan berkata, "It grew up in a context where belief in divine intervention was widespread". Lampe menunjukkan syarat yang serupa dengan berkata, "The model of a descent and an ascent of the Son of God serves only to confuse our Christology; the affirmation of Christ's descent into this world from another is mythological". 46 Jadi, kedua pendapat di atas hendak menggambarkan inkarnasi sebagai intervensi Ilahi, sehingga secara filosofi akan menimbulkan kebingungan dalam Kristologi itu sendiri. Mengapa? Oleh karena tidak mungkin Allah memiliki hubungan dengan dunia materi, karena Dia adalah transenden. Dengan demikian, hal itu adalah mitos.

Seperti yang dikutip oleh Macleod, Lampe menambahkan, "We should try to set the Christevent within the perspective of a continuous process of which we can discern neither the beginning nor the end, and to avoid the idea that in Christ God has broken into that creative process in which he is always immanent, and radically altered his own relationship to his human creation”. 47 Pendapat Lampe ini hendak menegaskan tentang perlunya untuk merumuskan ulang 'Peristiwa Kristus' di dalam perspektif sebuah proses yang berkelanjutan di mana dapat dilihat bukan hanya permulaan atau akhir, tetapi juga untuk menjauhi konsep ke-Allah-an Kristus telah hancur dalam proses yang mampu menciptakan bahwa dia adalah imanen. Dan secara radikal telah merubah hubungan-Nya dengan manusia ciptaan-Nya. Dalam proses filosofi, hal ini tidak mungkin.

Dalam kaitannya dengan sesuatu yang abstrak di atas, hal yang penting bagi Pittenger, seperti yang dikutip oleh Macleod adalah, "The language which has been used about Jesus Christ has almost consistently been such that he has been made to look like an intrusion or eruption from outside into the sphere of human life and experience.... Incarnation as an intrusion has no conceivable meaning save on a deistic conception of God as himself outside the world".48 Jadi menurut Pittenger, bahwa istilah yang digunakan untuk Yesus Kristus dalam proses filosofi hampir dengan konsisten menunjukkan seperti sebuah 'pemaksaan' atau 'letusan' yang berasal dari luar kehidupan manusia dan pengalamannya. Dengan demikian proses filosofi memahami inkarnasi sebagai sebuah pemaksaan yang tidak dapat dibayangkan makna keselamatan pada sebuah konsep dari Allah pada dirinya sendiri bersifat transenden. Menegaskan inkarnasi adalah sesuatu yang mustahil.

Pandangan seperti di atas sangat tidak alkitabiah. Oleh karena Allah yang adalah Pencipta dunia ini pasti memiliki hubungan erat dengan ciptaan-Nya (yaitu dunia dan segala isinya). Meskipun Allah transenden adanya, akan tetapi bukankah Allah juga telah menyatakan diri-Nya melalui inkarnasi-Nya.

Sepertinya Kant memberikan sedikit jalan keluar dari permasalahan ini. Bagi Kant, manusia memiliki a priori dalam rasionya, sehingga dalam berbicara tentang Allah, pengalaman dianalisis dalam otak manusia secara a priori. Bagi Kant, pengalaman itu dapat dibagi ke dalam tiga bentuk definisi, yakni: psikologi-teologi, kosmologi, dan ontologi. Dari pengalaman, mengantar manusia pada konsep transendensi, bahwa segala diskusi tentang Allah hanya sebatas pada spekulasi manusia saja. Di sinilah iman diperlukan, sebab Allah pada kenyataannya tidak bisa dibuktikan

\footnotetext{
46 Ibid., p. 248.

47 Ibid., p. 248.

48 Ibid., pp. 248-9.
} 
hanya dengan pengalaman inderawi semata. Allah melampaui hal-hal rasio murni.49 Tentu solusi dari Kant ini bukanlah sebuah solusi yang final.

Apa yang dikatakan Alkitab tentang relasi Allah dengan dunia? Paulus dalam suratnya kepada jemaat di Kolose menjelaskan bahwa, "Ia ada terlebih dahulu dari segala sesuatu dan segala sesuatu ada di dalam Dia" (1:17). Kemudian dalam Injil yang ditulisnya, Yohanes menegaskan bahwa, "Terang yang sesungguhnya, yang menerangi setiap orang, sedang datang ke dalam dunia" (1:9) dan kemudian, "Ia datang kepada milik kepunyaan-Nya, tetapi orang-orang kepunyaan-Nya itu tidak menerima-Nya" (1:11). Ayat-ayat di atas menegaskan bahwa Allah masih memiliki relasi dengan dunia ciptaan-Nya, terlebih pada saat inkarnasi Yesus. Di mana Yesus adalah Allah yang turut menciptakan dunia bersama Bapa dan Roh Kudus.

\section{Kesimpulan: Dampaknya bagi Kekristenan}

Semua Kristologi dalam teologi (dunia) modern secara langsung berdampak kepada kekristenan itu sendiri. Di mana agama Kristen kehilangan sifat eksklusifnya, dan sebaliknya yang muncul adalah inklusifisme, universalisme atau bahkan pluralisme. Dalam arti, agama Kristen kehilangan keunikan yang sebenarnya di tengah-tengah agama-agama dunia.

\section{Secara Doktrinal}

Dampak yang ditimbulkan dalam konteks ajaran menjadi sangat urgen dan krusial. Oleh karena doktrin Kristen kehilangan sifat eksklusifnya. Misalnya:

a. Yesus memang pernah hidup dalam sejarah. Akan tetapi semua pemberitaan yang disampaikan-Nya adalah tentang Bapa (Kerajaan Allah). Sehingga Dia pasti bukanlah seorang Juruselamat. Akan Gereja mula-mulalah yang berjasa menjadikan Yesus sebagai Tuhan dan Juruselamat.

b. Konsep inkarnasi Yesus hanya merupakan ciptaan gereja mula-mula. Pada dirinya sendiri, Yesus tidak merasa melalui cara yang demikian. Sehingga sebutan Anak Allah, Allah Anak, Mesias dan kemudian Tritunggal, itu semua adalah produk Gereja.

c. Yesus Kristus bukan satu-satunya juruselamat. Ada kemungkinan dalam agama-agama yang lain juga akan muncul juruselamat-juruselamat yang lain. Kesaksian Perjanjian Baru sendiri tentang Yesus masih samar-samar.

d. Doktrin Trinitas itu tidak pernah ada. Roh Kudus hanyalah mitos, sedangkan Yesus hanyalah manusia biasa yang memiliki jabatan sebagai nabi yang hebat karena mampu melakukan mujizat. Pre-eksistensi dan Post-eksistensi Yesus itu tidak pernah ada.

e. Kristologi atau Yesus Kristus harus dipahami secara ortopraksis, bukan ortodoksi.

f. Secara hakikat, Yesus bukanlah Allah. Akan tetapi Dia menjadi Allah setelah Dia berinkarnasi dan menyatakan kasih Allah.

g. Allah harus dipahami dalam aspek transendensi. Sehingga tidak mungkin lagi memiliki hubungan dengan dunia. Itulah sebabnya ajaran Allah yang berinkarnasi menjadi sangat membingungkan.

h. Agama Kristen adalah agama yang mengajarkan tentang mitos-mitos. Oleh karena Perjanjian Baru pun dianggap sebagai mitos. Bahkan semua doktrin dalam gereja yang berkisar tentang Kristus adalah rekayasa Gereja mula-mula.

\section{Secara Praktis}

Seperti yang dikatakan oleh Rasul Paulus dalam suratnya kepada jemaat di Korintus, bahwa 'Tetapi andaikata Kristus tidak dibangkitkan, maka sia-sialah pemberitaan kami dan sia-sialah juga kepercayaan kamu' (1 Kor. 15: 14). Hal ini memiliki kesamaan dengan permasalahan yang ditimbulkan oleh pandangan teologi modern tentang kristologi. Andaikata semua ajaran Kristen

\footnotetext{
49 http://id.wikipedia.org/wiki/Filsafat_ketuhanan/20/10/2012//
} 
adalah mitos, maka sia-sia untuk bertekun dalam iman kepada Yesus, sia-sia untuk berjuang mempertahankan iman kepada Yesus, dan sia-sia untuk memberitakan Injil kepada dunia. Toh, semuanya hanya mitos. Sia-sialah darah orang Kristen yang tertumpah karena Injil.

Kiranya tulisan ini dapat menjadi peringatan bagi Gereja untuk berhati-hati, senantiasa berjaga-jaga dan berdoa. Sehingga Tuhan memberikan hikmat-Nya guna memahami Injil yang benar, dan sebaliknya Injil yang bohong.

\section{Literatur}

\section{Buku-buku:}

Adiprasetya, Joas. Mencari Dasar Bersama. Jakarta: BPK Gunung Mulia, 2009.

Evans, Gallian R., Alister E. McGrath dan Allan D. Galloway. The Science Of Theology Volume One. Michigan: Grand Rapids, 1986. [Editor: Paul Avis].

Grenz, Stanley J., dan Roger E. Oslon, 20TH Century Theology. God and the World in a Transitional Age, (Illinois. USA: InterVarsity Press, 1992).

Knitter, Paul F.. Pengantar Ke Dalam Teologi Agama-Agama. Yogyakarta: Kanisius, 2008.

Kreeft, Peter, dan Ronald K. Tacelli. Pedoman Apologetik Kristen Jilid 1. Bandung: Yayasan Kalam Hidup, 2006. Cetakan Kedua.

Lumintang, Stevry Indra. Teologi Abu-abu. Pluralisme Iman: Kristologi Abu-abu. Malang: Departemen Literatur YPPII, 2002. (dalam bentuk PDF).

Macleod, Donald. The Person Of Christ. Contours of Christian Theology. Illinois: InterVarsity Press, 1998.

Nash, Ronald H. Konflik Wawasan Dunia. Surabaya: Momentum, 2008.

Penyusun, Tim. Kamus Besar Bahasa Indonesia Edisi Ketiga. Jakarta: Balai Pustaka, 2002.

Wellem, F. D.. Riwayat Hidup Singkat Tokoh-tokoh dalam Sejarah Gereja. Jakarta: BPK Gunung Mulia, 2011.

Wilson, John E..Introduction to Modern Theology. Trajectories in the German Tradition. London: Westminster John Knox Press, 2007.

\section{Internet:}

http://id.wikipedia.org/wiki/Rudolf_Bultmann

http://id.wikipedia.org/wiki/Eksistensialisme

http://id.wikipedia.org/wiki/Rudolf_Bultmann

http://alkitab.sabda.org/resource.php?topic $=1046 \&$ res $=j p z$

http://id.wikipedia.org/wiki/Paul_F._Knitter

http://id.wikipedia.org/wiki/Unitarianisme

http://id.wikipedia.org/wiki/Teologi_pembebasan

http://id.wikipedia.org/wiki/Teologi_pembebasan

http://en.wikipedia.org/wiki/Oscar_Cullmann

http://id.wikipedia.org/wiki/Filsafat_ketuhanan

http://id.wikipedia.org/wiki/John_Hick 